Doi: HTTPS://DOI.ORG/10.23910/2/2020.0370

\title{
Effect of Next Generation Fertilizers on Growth and Yield Potential of Maize (Zea mays L.)
}

\author{
M. A. A. Faroque ${ }^{1 *}$, Alok Kumar Paul' ${ }^{2}$ Asaduzzaman², Parimal Bissus² and M. S. Islam ${ }^{3}$
}

${ }^{1}$ Project Implementation Unit, National Agricultural Technology Program Phase II Project, Bangladesh Agricultural Research Council, Farmgate, Dhaka (12 15), Bangladesh

${ }^{2}$ Sher-e-Bangla Agricultural University, Dhaka (12 07), Bangladesh

${ }^{3}$ Bangladesh Agricultural Research Institute, Gazipur (17 01), Bangladesh

\section{Corresponding Author}

M. A. A. Faroque

e-mail: faroquekbd@gmail.com

\begin{abstract}
Article History
Article ID: IJEP0370

Received in $26^{\text {th }}$ March, 2020

Received in revised form 09 ${ }^{\text {th }}$ May, 2020

Accepted in final form $29^{\text {th }}$ May, 2020
\end{abstract}

\begin{abstract}
To reduce the existing yield gap of maize crop between research and farmer's field, the experiment was carried out during the period from March, 2014 to June, 2014 at the experimental field of Sher-e-Bangla Agricultural University, Sher-e-Bangla Nagar, Dhaka, Bangladesh. The experiments were laid out in RCBD method with three replications and eight treatments including control viz. Treatment ${ }_{0}=$ control $_{\text {(no }}$ fertilizer), Treatment ${ }_{1}=$ recommended dose $\mathrm{N}_{250} \mathrm{P}_{50} \mathrm{~K}_{100} \mathrm{~S}_{25} \mathrm{Zn}_{2} \mathrm{~B}_{1} \mathrm{~kg}^{-1}$, Treatment ${ }_{2}=$ American NPK $+\mathrm{N}_{250} \mathrm{P}_{50} \mathrm{~K}_{100} \mathrm{~S}_{25} \mathrm{Zn}_{2} \mathrm{~B}_{1}$, Treatment $3=$ Bioforge $+\mathrm{N}_{250} \mathrm{P}_{50} \mathrm{~K}_{100} \mathrm{~S}_{25} \mathrm{Zn}_{2} \mathrm{~B}_{1}$, Treatment $=$ Wuxal $+\mathrm{N}_{250} \mathrm{P}_{50} \mathrm{~K}_{100} \mathrm{~S}_{25} \mathrm{Zn}_{2} \mathrm{~B}_{1}$, Treatment ${ }_{5}=$ Peak $+\mathrm{N}_{250} \mathrm{P}_{50} \mathrm{~K}_{100} \mathrm{~S}_{25} \mathrm{Zn}_{2} \mathrm{~B}_{1}$, Treatment ${ }_{6}=$ Root Feed $+\mathrm{N}_{250} \mathrm{P}_{50}$ $\mathrm{K}_{100} \mathrm{~S}_{25} \mathrm{Zn}_{2} \mathrm{~B}_{1}$ and Treatment ${ }_{7}=$ Nitro Plus $+\mathrm{N}_{250} \mathrm{P}_{50} \mathrm{~K}_{100} \mathrm{~S}_{25} \mathrm{Zn}_{2} \mathrm{~B}_{1}$ and three maize varieties namely Variety ${ }_{1}=\mathrm{BARI}$ Hybrid Bhutta-5, Variety ${ }_{2}=\mathrm{BARI}$ Hybrid Bhutta-6 and Variety ${ }_{3}=$ BARI Hybrid Bhutta-9. Growth and yield contributing characters mainly plant height, cob length, cob weight, 100-kernel weight and kernel yield of maize crop were significantly influenced by the next generation fertilizers. Bio-forge along with other recommended fertilizers performed the best compared to other treatments of the study in aspect of kernel yield $\left(5.95 \mathrm{tha} \mathrm{a}^{1}\right)$ and statistically similar result showed by Root Feed along with other recommended fertilizers and produced $5.12 \mathrm{t} \mathrm{ha}{ }^{1}$ kernel yield.
\end{abstract}

Keywords: Maize, next generation, fertilizer, growth and yield

\section{Introduction}

Bangladesh is a densely populated and agriculture based country. Agriculture is the main stem of livelihood for more than $80 \%$ of the country's population. The main purpose of agriculture is to provide food for the increasing population. Fertilizer is considered one of the main inputs for increasing crop yields and farmer's profit. It is true for Bangladesh agriculture because it has virtually no possibility of increasing its cultivable land area.

In early 1950's, farmers applied organic manures (first generation) such as cow dung, bone meal to aus and aman rice and farmyard manure (FYM), mustard oil cake and fish meal to mustard and vegetable crops (EPBS, 1958). The use of inorganic fertilizer (second generation) started in the country in 1951 with the import of 2,698 tons of ammonium sulphate, phosphates in 1957 and muriate of potash in 1960. After 1971, Bangladesh experienced magnificent increase in food production due to effect of green revolution. Thus, fertilizer consumption began to increase rapidly with the introduction of HYV rice.

Food security has become a major and fast growing concern worldwide. It is proposed that there is a need to double the world food production in order to feed the ever increasing population which is set to reach nine billion marked by 2050 (UN, 2009). The farmers of Bangladesh could not harvest additional yield from crops due to lack of knowledge in using of next generation fertilizers, although the role of growth controlling in various physiological and biochemical processes is well known. But still some hidden hunger is remaining in plants, even though some farmers are following recommended fertilizer done under IPNS basis. As a result farmer are not getting desired yield of the crops. So, Next generation fertilizer is nutritional mixed fertilizers to provide total nutritional requirements for plants without compromising on productivity while protecting ecology and also address "First Generation" \& "Second Generation" fertilizer.

Bangladesh need continue efforts to search effective and usable means of improving NPKS use efficiency and alternative sources of fertilizer for reducing the yield gap. It has no alternative to maximize crop yields per unit area through intensive use of land and soil resources. With this view the research will be taken out on next generation fertilizer products for soil fertility and increasing crop production. So 
many researches had taken initiative on fertilizer management like effect, doses and timing etc. but no enough research on next generation fertilizer materials are still found.

\section{Materials and Methods}

\subsection{Study sites}

The experiment was conducted for maize during March 2014 to June 2014. The experimental area was situated at $23^{\circ} 77^{\circ} \mathrm{N}$ latitude and $90^{\circ} 33^{\circ} \mathrm{E}$ longitude at an altitude of 8.6 meter above the sea level. The experimental field belongs to the Agro-ecological zone of "The Modhupur Tract", AEZ-28. The experimental area was flat having available irrigation and drainage system and above flood level. The area has sub tropical climate, characterized by high temperature, high relative humidity and heavy rainfall with occasional gusty winds in Kharif-1 season (Mid Feb-Mid June). Soil samples from 0-15 cm depths were collected from experimental field. Physical and chemical properties of the initial soil sample was found Sand $28.2 \%$, Silt $41.2 \%$, Clay $30.6 \%$, Textural class- clay loam, pH-5.8, bulk density-1.45 $\mathrm{g} \mathrm{cc}^{-1}$, particle density-2.52 g cc $^{-1}$, organic carbon- $0.62 \%$, organic matter- $1.07 \%$, total $\mathrm{N}-0.06 \%$, available P-25.75 ppm, exchangeable K-0.14 meq $100 \mathrm{~g}^{-1}$ soil and available S- $11.75 \mathrm{ppm}$.

\subsection{Method of data collection}

Three varieties of maize were used in this experiment for growth measurement under six next generation fertilizers with control following a two factor experiment in RCBD design with 03 (three) replications. Factor A: NGF + recommended fertilizers with control (8) Factor B: Varieties (3).

On 24 March 2014, seeds were sown in the experiment field keeping plant to plant distance $20 \mathrm{~cm}$ and row to row distance $75 \mathrm{~cm}$. The triple super phosphate (TSP), muriate of potash (MoP), gypsum $\left(\mathrm{CaSO}_{4}\right)$ zinc sulphate and boron (boric acid) fertilizers were applied in the experimental plots @ $P_{50^{\prime}}$ $\mathrm{K}_{100}, \mathrm{~S}_{25}, \mathrm{Zn}_{2}$ and $\mathrm{B}_{1} \mathrm{~kg} \mathrm{ha}^{-1}$, respectively as basal dose in the experimental plots except control plots. The recommended dose of $\mathrm{N}$ was $250 \mathrm{~kg} \mathrm{ha}^{-1}$. $\mathrm{N}$ was applied as per treatment in three equal splits. The first split was applied as basal dose in the preparation of experimental layout. In the time of tassel initiation or opening of 8-10 leaves, the second split was applied and one week before silking or gain filling the third split was applied. The next generation fertilizers American NPKS, Bio-forge, Wuxal Super, Peak, Root feed and NiroPlus were sprayed at 25, 45 and 65 DAS on plants of the experimental plots @ 9.88 I ha-1, $1.201 \mathrm{ha}^{-1}, 5.0 \mathrm{I} \mathrm{ha}{ }^{-1}, 1.2 \mathrm{~kg}$ $\mathrm{ha}^{-1} 1.20 \mathrm{~kg} \mathrm{ha}^{-1}$, and $1.2 \mathrm{I} \mathrm{ha-1}$ respectively.

The cobs were harvested at maturity on 27 June, 2014. The harvested cobs were threshed plot-wise. Kernel and Stover yields were recorded separately plot-wise and moisture percentage was calculated after sun drying. The selected plants were collected before harvesting. Kernel and Stover yields were recorded plot-wise and expressed at $\mathrm{t} \mathrm{ha}^{-1}$ on sundry basis.

Data recorded for yield and yield contributing characters were compiled and tabulated in proper form for statistical analyses. Analysis of variance was done with the help of MSTAT-C computer package program developed by Russel (1986). The mean differences among the treatments were evaluated with DMRT test (Gomez and Gomez, 1984).

\section{Results and Discussion}

\subsection{Plant height}

Plant height varied significantly due to the effect of next generation fertilizers along with other recommended fertilizers at harvest while plant height ranges from $129.1 \mathrm{~cm}$ to $151.0 \mathrm{~cm}\left(L S D_{0.05}=6.803\right)$ (Table 1). It is also revealed that

Table 1: Effect of NGF and other recommended fertilizers on yield and yield contributing characters of maize

\begin{tabular}{lccccc}
\hline Fertilizers & Plant height $(\mathrm{cm})$ & Cobs plant $^{-1}($ No.) & Cob length $(\mathrm{cm})$ & 100 - kernel weight $(\mathrm{g})$ & Kernel yield $\left(\mathrm{t} \mathrm{ha}^{-1}\right)$ \\
\hline $\mathrm{T}_{0}$ & $129.1^{\mathrm{d}}$ & 1.09 & $19.24^{\mathrm{d}}$ & $27.06^{\mathrm{c}}$ & $2.37^{\mathrm{c}}$ \\
$\mathrm{T}_{1}$ & $143.1^{\mathrm{bc}}$ & 1.17 & $20.33^{\mathrm{cd}}$ & $27.99^{\mathrm{bc}}$ & $4.1^{\mathrm{b}}$ \\
$\mathrm{T}_{2}$ & $144.0^{\mathrm{bc}}$ & 1.24 & $21.50^{\mathrm{b}-\mathrm{d}}$ & $28.23^{\mathrm{bc}}$ & $4.75^{\mathrm{b}}$ \\
$\mathrm{T}_{3}$ & $151.0^{\mathrm{a}}$ & 1.27 & $23.00^{\mathrm{a}}$ & $30.31^{\mathrm{a}}$ & $5.83^{\mathrm{a}}$ \\
$\mathrm{T}_{4}$ & $133.8^{\mathrm{cd}}$ & 1.22 & $20.30^{\mathrm{cd}}$ & $28.22^{\mathrm{bc}}$ & $3.83^{\mathrm{b}}$ \\
$\mathrm{T}_{5}$ & $141.3^{\mathrm{bc}}$ & 1.27 & $20.45^{\mathrm{cd}}$ & $28.44^{\mathrm{bc}}$ & $3.80^{\mathrm{b}}$ \\
$\mathrm{T}_{6}$ & $149.0^{\mathrm{ab}}$ & 1.23 & $21.71^{\mathrm{b}}$ & $29.69^{\mathrm{ab}}$ & $5.82^{\mathrm{ab}}$ \\
$\mathrm{T}_{7}$ & $143.4^{\mathrm{bc}}$ & 1.26 & $21.52^{\mathrm{b}-\mathrm{d}}$ & $28.25^{\mathrm{bc}}$ & $3.89^{\mathrm{b}}$ \\
LSD $(p=0.05)$ & 6.80 & & 1.252 & 1.62 & 1.05 \\
Level of Significance & $* *$ & $\mathrm{NS}$ & $*$ & $*$ & $*$ \\
\hline
\end{tabular}

Figures having similar letter (s) do not differ significantly; *,**: Significant at $(p=0.05)$ and $(p=0.01)$ level of probability; Here, $T_{0}$ : Control (No fertilizer); $\mathrm{T}_{1}$ : Recommended $\mathrm{N}_{250} \mathrm{P}_{50} \mathrm{~K}_{100} \mathrm{~S}_{25} \mathrm{Zn}_{2} \mathrm{~B}_{1} \mathrm{~kg}_{\mathrm{ha}}{ }^{-1} ; \mathrm{T}_{2}$ : American NPK $\left(9.88 \mathrm{I} \mathrm{ha}{ }^{-1}\right)+$ Recommended $^{-1}$ $\mathrm{N}_{250} \mathrm{P}_{50} \mathrm{~K}_{100} \mathrm{~S}_{25} \mathrm{Zn}_{2} \mathrm{~B}_{1}, \mathrm{~T}_{3}$ : Bio-forge (1.20 I ha-1 $)$ +Recommended $\mathrm{N}_{250} \mathrm{P}_{50} \mathrm{~K}_{100} \mathrm{~S}_{25} \mathrm{Zn}_{2} \mathrm{~B}_{1} ; \mathrm{T}_{4}$ : Wuxal Super (5.00 I ha $\left.{ }^{-1}\right)+\mathrm{Recommended}$ $\mathrm{N}_{250} \mathrm{P}_{50} \mathrm{~K}_{100} \mathrm{~S}_{25} \mathrm{Zn}_{2} \mathrm{~B}_{1} ; \mathrm{T}_{5}$ : Peak (1.20 kg ha $\left.{ }^{-1}\right)+$ Recommended $\mathrm{N}_{250} \mathrm{P}_{50} \mathrm{~K}_{100} \mathrm{~S}_{25} \mathrm{Zn}_{2} \mathrm{~B}_{1} ; \mathrm{T}_{6}$ : Root Feed (1.20 kg ha $\left.{ }^{-1}\right)+$ Recommended $\mathrm{N}_{250} \mathrm{P}_{50} \mathrm{~K}_{100} \mathrm{~S}_{25} \mathrm{Zn}_{2} \mathrm{~B}_{1} ; \mathrm{T}_{7}^{5}$ : Nitro Plus $\left(1.20 \mathrm{I} \mathrm{ha} \mathrm{h}^{-1}\right)+$ Recommended $\mathrm{N}_{250} \mathrm{P}_{50} \mathrm{~K}_{100}^{25} \mathrm{~S}_{25} \mathrm{Zn}_{2} \mathrm{~B}_{1}$ 
the tallest plant of $151.0 \mathrm{~cm}$ was found from the treatment $T_{3}$ receiving Bio-forge along with other recommended fertilizers which was statistically similar with treatment $T_{6}(149.0 \mathrm{~cm})$ (Table 1). Such effect of Bio-forge with other recommended fertilizers on plant height might be associated with the stimulating effect of Bio-forge and $\mathrm{N}$ on various physiological processes including cell division and cell elongation of the plant. Among the three varieties, BARI Hybrid Bhutta-9 plant was the tallest $(151.0 \mathrm{~cm})$ which was statistically similar to BARI Hybrid Bhutta-6 plant $(148.3 \mathrm{~cm})$ during the kharif-1 season (Table 2). Asghar et al. (2010) found that the plant height was not significantly affected by maize cultivars; Golden and Sultan. Besides, the climatic and soil condition of the studied area were favorable for better growth of BARI Hybrid Bhutta-9 which ultimately showed highest plant height than BARI Hybrid Bhutta-5. The highest plant height of 157.8 $\mathrm{cm}$ was found in the treatment combination $\mathrm{T}_{3} \mathrm{~V}_{3}$ (Bio-forge along with recommended fertilizers and BARI Hybrid Bhutta-9) which was statistically different with the other treatments except treatment combination of $\mathrm{T}_{6} \mathrm{~V}_{1}(151.6 \mathrm{~cm})$ (Table 3).

\subsection{Numbers of cobs plant ${ }^{-1}$}

Number of cobs plant ${ }^{-1}$ of maize was not statistically significant but numerically varied among the treatments of next generation fertilizers along with other recommended fertilizers (Table 1). The highest mean number of cobs (1.27) was obtained in the treatment $T_{3}$ having Bio-forge along with other recommended fertilizers and also observed in $\mathrm{T}_{5}$ having Peak along with other recommended fertilizers. Similar findings also agreed by the research work of Rogaciano and Rosill (2015), Amali and Namo (2015), Yihenew (2015) and other researchers of the home and abroad. Though the effect of varieties on number of cobs was statistically insignificant but maximum numbers of cobs were found in the treatment $V_{3}(1.34)$ and minimum number of cobs (1.17) found in the variety $V_{2}$ (Table 2 ). This result is in agreement with the

Table 2: Effect of varieties on yield and yield contributing characters of maize

\begin{tabular}{|c|c|c|c|c|c|}
\hline Fertilizers & Plant height (cm) & Cobs plant ${ }^{-1}$ (No.) & Cob length $(\mathrm{cm})$ & 100 kernel weight (g) & Kernel yield $\left(\mathrm{t} \mathrm{ha}^{-1}\right)$ \\
\hline $\mathrm{V}_{1}$ & $142.0^{b}$ & 1.17 & $21.78^{b}$ & $26.03^{b}$ & $4.45^{c}$ \\
\hline $\mathrm{V}_{2}$ & $148.3^{a}$ & 1.16 & $21.89^{b}$ & $26.20^{b}$ & $4.52^{b}$ \\
\hline $\mathrm{V}_{3}$ & $151.0^{\mathrm{a}}$ & 1.34 & $22.87^{a}$ & $28.01^{a}$ & $5.83^{\mathrm{a}}$ \\
\hline LSD (0.05) & 4.166 & - & 0.767 & 0.99 & 1.31 \\
\hline Level of Significance & $* *$ & NS & $*$ & $*$ & $*$ \\
\hline
\end{tabular}

Figures having similar letter (s) do not differ significantly; $*, * *$ : Significant at $(p=0.05)$ and $(p=0.01)$ level of probability; Here, $V_{1}=$ BARI Hybrid Bhutta-5, $V_{2}=$ BARI Hybrid Bhutta-6, $V_{3}=$ BARI Hybrid Bhutta- 9

findings of Idris et al. (2016), Amali and Namo (2015) and many other scientists. They also found variation in number of cobs per plant due to the variation in genetic makeup of the varieties of maize. The cob numbers at harvest did not differ varied significantly due to the effect of interaction of treatment combination of next generation fertilizer with other recommended fertilizers and variety (Table 3 ). The maximum number of cobs per plant (1.5) was found from $\mathrm{T}_{3} \mathrm{~V}_{3}$, the variety BARI Hybrid Bhutta-9 receiving Bio-forge along with other recommended fertilizers.

\subsection{Cob length}

The cob length of maize showed significant variation among the next generation fertilizers $\left(L_{S D} D_{0.05}=1.252\right)$ (Table 1$)$. The longest cob $(23.00 \mathrm{~cm})$ was obtained from the treatment $T_{3}$ having Bio-forge along with other recommended fertilizers which was statistically differed from other treatments. The shortest cob length $(19.24 \mathrm{~cm})$ was found $T_{0}$ treatment which was statistically similar with $\mathrm{T}_{1}, \mathrm{~T}_{2}, \mathrm{~T}_{4^{\prime}} \mathrm{T}_{5}$ and $\mathrm{T}_{7}$ treatments. These result reveled that Bio-forge along with other recommended fertilizers was highly effective than other next generation fertilizers along with other recommended fertilizers to produced longest cob. Maulana et al. (2015) found that the Bio liquid fertilizer Ultra Gen was significantly effective in increasing cob length.

Cob length was significantly influenced by the variety (Table 2). It was found that the longest cob $(22.87 \mathrm{~cm})$ was observed in the variety $V_{3}$ (BARI Hybrid Bhutta-9). Cob length at harvest varied significantly due to the effect of interaction of treatment next generation fertilizer and variety. From the table 3, it was found that cob length varied from $20.20 \mathrm{~cm}$ to $23.67 \mathrm{~cm}$. The maximum cob length of $23.67 \mathrm{~cm}$ was found from treatment combination of $\mathrm{T}_{3} \mathrm{~V}_{3}$ which was statistically similar with the treatment combination of $\mathrm{T}_{6} \mathrm{~V}_{3}$.

\subsection{Hundred kernel weight}

The next generation fertilizer along with other recommended fertilizers showed significant effect on 100 kernel weight $\left(L S D_{0.05}=1.62\right)$ (Table 1). Among the treatments, treatment combination $\mathrm{T}_{3}$, Bio-forge along with other recommended fertilizers showed effect on the maximum 100 kernel weight (30.31 g) which was statistically similar to treatment of $T_{6}$ (29.69 g). These result indicated that kernel size increased significantly with the application of next generation fertilizer along with other recommended fertilizers which might be supplied adequate nutrients in certain levels. Similar result was agreed by Ali et al. (2016) through a study to applied extract fertilizer spraying led to significant increase yield 
Table 3: Interaction of NGF along with other recommended fertilizers and variety on plant height, yield contributing characters and yield of maize

\begin{tabular}{|c|c|c|c|c|c|}
\hline Fertilizers & Plant height $(\mathrm{cm})$ & Cobs plant ${ }^{-1}$ (No.) & Cob length $(\mathrm{cm})$ & 100 kernel weight (g) & Yield $\left(\mathrm{t} \mathrm{ha}^{-1}\right)$ \\
\hline $\mathrm{T}_{0} \times \mathrm{V} 1$ & $129.9^{\text {ef }}$ & 0.88 & $20.20^{d}$ & $24.59^{c}$ & $1.97^{c}$ \\
\hline $\mathrm{T}_{0} \times \mathrm{V} 2$ & $129.8^{\mathrm{ef}}$ & 1.10 & $20.88^{\text {cd }}$ & $24.68^{c}$ & $2.33^{c}$ \\
\hline $\mathrm{T}_{0} \times \mathrm{V} 3$ & $127.0^{\mathrm{ef}}$ & 1.29 & $20.71^{c d}$ & $24.72^{c}$ & $2.73^{c}$ \\
\hline $\mathrm{T}_{1} \times \mathrm{V}_{1}$ & $137.8^{\text {de }}$ & 1.13 & $21.37^{\mathrm{bc}}$ & $25.21^{b c} \mathrm{c}$ & $4.22^{\mathrm{bc}}$ \\
\hline $\mathrm{T}_{1} \times \mathrm{V}_{2}$ & $141.2^{\text {cd }}$ & 1.17 & $21.34^{\mathrm{bc}}$ & $24.82^{\mathrm{bc}}$ & $3.55^{\mathrm{bc}}$ \\
\hline $\mathrm{T}_{1} \times \mathrm{V}_{3}$ & $147.7^{b c}$ & 1.23 & $22.25^{\mathrm{bc}}$ & $24.97^{\mathrm{bc}}$ & $4.24^{\mathrm{b}}$ \\
\hline $\mathrm{T}_{2} \times \mathrm{V}_{1}$ & $142.0^{\text {cd }}$ & 1.19 & $22.01^{\mathrm{bc}}$ & $26.18^{\mathrm{bc}}$ & $4.18^{\mathrm{bc}}$ \\
\hline $\mathrm{T}_{2} \times \mathrm{V}_{2}$ & $141.0^{\text {cd }}$ & 1.15 & $21.60^{\mathrm{bc}}$ & $25.80^{\mathrm{bc}}$ & $4.11^{\mathrm{bc}}$ \\
\hline$T_{2} \times V_{3}$ & $146.7^{b c}$ & 1.38 & $22.9^{b c}$ & $25.77^{\mathrm{bc}}$ & $4.25^{b}$ \\
\hline $\mathrm{T}_{3} \times \mathrm{V}_{1}$ & $149.1^{\mathrm{bc}}$ & 1.19 & $22.20^{\mathrm{bc}}$ & $26.41^{\mathrm{bc}}$ & $4.22^{\mathrm{bc}}$ \\
\hline $\mathrm{T}_{3} \times \mathrm{V}_{2}$ & $144.5^{\mathrm{bc}}$ & 1.17 & $22.23^{\mathrm{bc}}$ & $26.18^{b c}$ & $4.25^{b}$ \\
\hline $\mathrm{T}_{3} \times \mathrm{V}_{3}$ & $157.8^{\mathrm{a}}$ & 1.50 & $23.67^{a}$ & $28.05^{\mathrm{a}}$ & $5.95^{\mathrm{a}}$ \\
\hline $\mathrm{T}_{4} \times \mathrm{V}_{1}$ & $134.4^{\text {de }}$ & 1.15 & $21.66^{b c}$ & $26.07^{b c}$ & $4.26^{b}$ \\
\hline $\mathrm{T}_{4} \times \mathrm{V}_{2}$ & $135.4^{\text {de }}$ & 1.17 & $22.35^{\mathrm{bc}}$ & $26.21^{\mathrm{bc}}$ & $4.25^{b}$ \\
\hline $\mathrm{T}_{4} \times \mathrm{V}_{3}$ & $147.7^{\mathrm{bc}}$ & 1.31 & $21.20^{\mathrm{bc}}$ & $25.68^{\mathrm{bc}}$ & $4.22^{\mathrm{bc}}$ \\
\hline$T_{5} \times V_{1}$ & $141.0^{\text {cd }}$ & 1.10 & $21.79^{b c}$ & $25.93^{b c}$ & 3. $24^{b}$ \\
\hline$T_{5} \times V_{2}$ & $143.0^{\text {cd }}$ & 1.27 & $21.58^{b c}$ & $25.10^{\mathrm{bc}}$ & $4.10^{\mathrm{bc}}$ \\
\hline $\mathrm{T}_{5} \times \mathrm{V}_{3}$ & $145.8^{\mathrm{bc}}$ & 1.44 & $22.18^{b c}$ & $26.13^{b c}$ & $3.98^{b c}$ \\
\hline $\mathrm{T}_{6} \times \mathrm{V}_{1}$ & $151.6^{\mathrm{ab}}$ & 1.42 & $22.17^{\mathrm{bc}}$ & $26.16^{b c}$ & $4.22^{\mathrm{bc}}$ \\
\hline$T_{6} \times V_{2}$ & $149.9^{b c}$ & 1.08 & $22.38^{b c}$ & $26.26^{b c}$ & $4.25^{b}$ \\
\hline $\mathrm{T}_{6} \times \mathrm{V}_{3}$ & $146.1^{\mathrm{bc}}$ & 1.19 & $23.31^{\mathrm{ab}}$ & $27.45^{\mathrm{ab}}$ & $5.12^{\mathrm{ab}}$ \\
\hline $\mathrm{T}_{7} \times \mathrm{V}_{1}$ & $138.7^{\mathrm{cd}}$ & 1.35 & $21.63^{b c}$ & $25.96^{\mathrm{bc}}$ & $4.15^{b c}$ \\
\hline $\mathrm{T}_{7} \times \mathrm{V}_{2}$ & $137.2^{\text {de }}$ & 1.19 & $21.43^{b c}$ & $26.05^{b c}$ & $4.02^{\mathrm{bc}}$ \\
\hline $\mathrm{T}_{7} \times \mathrm{V}_{3}$ & $144.7^{b c}$ & 1.42 & $21.50^{\mathrm{bc}}$ & $26.28^{\mathrm{bc}}$ & $4.24^{b}$ \\
\hline LSD (0.05) & 6.78 & - & 1.169 & 1.63 & 1.70 \\
\hline Level of Significance & * & NS & * & * & * \\
\hline
\end{tabular}

Figures having similar letter (s) do not differ significantly; ${ }^{*}, * *$ : Significant at $(p=0.05)$ and $(p=0.01)$ level of probability

components (weight of 100 grains, and ear grain weight) and grain yield significantly compared with control. Yihenew (2015) who reported that there is no significant variation among treatments in 100 kernel weight of maize where $\mathrm{N}$ increase 90-200 $\mathrm{kg} \mathrm{ha}^{-1}$. Maulana et al. (2015) also found that no significant effect on weight of 100 grain dry seeds yield with the Bio liquid fertilizer Ultra Gen consisted of four levels, i.e. without liquid fertilizer $\left(P_{0}\right), 0.8$ liter ha-1 $\left(P_{1}\right), 1.7$ liter ha-1 $\left(P_{2}\right)$, and 2.5 liter ha-1 $\left(P_{3}\right)$. The effect of maize varieties on 100-kernel weight was statistically significant due to control of genetically makeup of variety. From the Table 2, it was found that variety $\mathrm{V}_{3}$, BARI Hybrid Bhutta-9 produce maximum 100-kernel weight (28.01 g) whereas minimum 100-kernel weight was found in $\mathrm{V}_{1}(26.03 \mathrm{~g})$ which was statistically similar to $V_{2}(26.20 \mathrm{~g})$. The maximum100 kernel weight of $28.05 \mathrm{~g}$ was found from the variety BARI Hybrid Bhutta-9 receiving
Bio-forge along with other recommended fertilizers $\left(T_{3} V_{3}\right)$ which was statistically similar with treatment combination $\mathrm{T}_{6} \mathrm{~V}_{3}(27.45 \mathrm{~g})$ (Table 3).

\subsection{Kernel yield}

A significant variation was found for the character of kernel yield due to the effect of next generation fertilizers along with other commanded fertilizers $\left(\mathrm{LSD}_{0.05}=1.05\right)$ (Table 1). Among the treatments, $\mathrm{T}_{3}$ (Bio-forge along with other commanded fertilizers) produced significantly the highest yield of kernel $5.83 \mathrm{t} \mathrm{ha}^{-1}$ which is similar to treatment $\mathrm{T}_{6}$ (Root feed along with other commanded fertilizers). Treatment $T_{0}$ showed the lowest yield of maize $\left(2.37 \mathrm{t} \mathrm{ha}^{-1}\right)$. This revealed that Bioforge+other recommended fertilizers and Root feed along with other recommended fertilizers showed the greater effect on kernel yield which might be due to the production of long 
cob, more kernels per cob and ability to overcome stress condition of Kharif- 1 season. The above findings indicated that the treatment combinations of $T_{3}$ and $T_{6}$ would be ideal for getting the highest kernel yield of maize. Similar findings found from the Idris et al. (2016) who conducted field experiments with the liquid bio-fertilizer (effective microorganism, EM) and found the highest grain yield. There was a significant difference between the varieties in respect of kernel yield $\left(L_{S D} D_{0.05}=1.31\right)$ (Table 2). Between the varieties, BARI Hybrid Bhutta-9 $\left(\mathrm{V}_{3}\right)$ produced the highest kernel yield (5.83 $\mathrm{tha}^{-1}$ ) where BARI Hybrid Bhutta-5 $\left(\mathrm{V}_{1}\right)$ produced the minimum yield $\left(4.45 \mathrm{t} \mathrm{ha}^{-1}\right)$. This variation in kernel yield found due to their genetic difference between the varieties. Asghar et al. (2010) investigated the effect of different NPK rates on growth and yield of maize cultivars; Golden and Sultan. The grain yield was significantly affected by different rates of NPK and varieties. The kernel yield of maize at harvest significantly varied due to the effect of interaction effect of treatment next generation fertilizer with other recommended fertilizers and variety where kernel yield varied from 1.97 to $5.95 \mathrm{t} \mathrm{ha}^{-1}$ (Table 3). The highest kernel yield of $5.95 \mathrm{t} \mathrm{ha}^{-1}$ was found from the variety BARI Hybrid Bhutta-9 receiving Bio-forge along with other recommended fertilizers of $\left(\mathrm{T}_{3} \mathrm{~V}_{3}\right)$ which was statistically similar with $\mathrm{T}_{6} \mathrm{~V}_{3}$ treatment combination. The lowest kernel yield of $1.97 \mathrm{t} \mathrm{ha}^{-1}$ was found from the variety BARI Hybrid Bhutta- 5 while it did not receive any levels of next generation fertilizer along with other recommended fertilizers $\left(T_{0} V_{1}\right)$ which was statistically similar with $\mathrm{T}_{0} \mathrm{~V}_{2}$ and $\mathrm{T}_{0} \mathrm{~V}_{3}$ treatment combinations.

\section{Conclusion}

Growth and yield contributing characters mainly plant height, cob length, cob weight, 100 kernel weight and kernel yield of maize crop were significantly influenced by the next generation fertilizers. Bio-forge along with other recommended fertilizers performed best as compared to other treatments of the study.

\section{Acknowledgment}

The authors are very grateful to Sayed Monena Montaj Foundation and National AgriCare Group, Dhaka for kind and financial support to conduct research work.

\section{References}

Ali, H.J., Khalid, N.A., Kadhum, M.H., 2016. Effect of spraying extracts concentration of three organic fertilizers on growth and yield of maize (Zea mays L.). Mesopotamia Environmental Journal- Special Issue B, 131-137.

Amali, P.E., Namo, O.A.T., 2015. Effect of time of fertilizer application on growth and yield of maize (Zea mays L.) in Jos - plateau environment. Global Journal of Agricultural Sciences 14, 1-9.

Asghar, A., Ali, A., Syed, W.H., Asif, M., Khaliq, T., Abid, A.A., 2010. Growth and yield of maize (Zea mays L.) cultivars affected by NPK application in different proportion. Pakistan Journal of Science 62, 111-114.

EPBS, 1958. The provincial statistical board and bureau of commercial industrial intelligence. Statistical Abstract for East Pakistan, Dacca, 517.

Gomez, K.A., Gomez, A.A., 1984. Statistical procedure for agricultural research. $2^{\text {nd }}$ ed. John Wiley and Sons. New York, 64.

Idris, A.E., Obid, S.A., Ahmed, B.E.A.M., 2016. Effect of biofertilizer on growth and yield of two maize (Zea mays L.) Cultivars at Shambat, Sudan. Scholars Journal of Agriculture and Veterinary Sciences 3, 313-317.

Maulana, Z., Zaitun, Z., Jumini, J., 2015. The effect of bioliquid fertilizer application on the growth and yield of two variety of maize (Zea mays L.). Proceedings of The $5^{\text {th }}$ Annual International Conference Syiah Kuala University (AIC Unsyiah) 2015 in conjunction with the 8th International Conference of Chemical Engineering on Science and Applications (ChESA) 2015 September 9-11, 2015, Banda Aceh, Indonesia, 224-227.

Rogaciano, D.D.J., Rosill, A.C., 2015. Effect of different liquid fertilizers on yield and economic analysis of glutinous corn (Zea mays L.). International Journal of Multidisciplinary Research and Development 2, 558-562.

Russel, D.F., 1986. MSTAT-C Package programme. Crop and Soil Science Department, Michigan State University, USA.

United Nations, 2009. Food production must double by 2050 to meet demand from world's growing population, innovative strategies needed to combat hunger. Sixtyfourth General Assembly, Second Committee GA/ EF/3242, Panel Discussion (AM). 9 October 2009. http:// www.un.org

Yihenew, G.S., 2015. The effect of $\mathrm{N}$ fertilizer rates on agronomic parameters, yield components and yields of maize grown on Alfisols of North-western Ethiopia. Environmental Systems Research 4, 21. 